\title{
STRATEGI PEMASARAN PAKAN SATWA UNGGUL BLITAR
}

\author{
Handika Rifki Widi Prasetyo ${ }^{1)}$, Yuli Arif Tribudi ${ }^{2)}$ Agustina Widyasworo Kunharjati ${ }^{3)}$ \\ ${ }^{1)}$ Mahasiswa Program Studi Ilmu Ternak Fakultas Peternakan Universitas Islam Balitar \\ 2) Dosen Program Studi Ilmu Ternak Fakultas Pertanian Universitas Tanjung Pura \\ 3) Dosen Program Studi Ilmu Ternak Fakultas Peternakan Universitas Islam Balitar \\ Fakultas Peternakan, Universitas Islam Balitar \\ J1. Majapahit No 4 Kelurahan Sananwetan Kota Blitar
}

\begin{abstract}
This study analyzes the marketing strategies of Pakan in PS SatwaUnggulBlitar views of the concept of the marketing mix. This case study research using descriptive analytic method with purposive sampling technique.Marketing mix strategy being conducted by PS Satwa Unggul are strategies related products (such as brand awareness on brand), pricing strategy (in the form of rebates), the distribution strategy (in the form of three patterns of distribution), and promotion strategies (in the form of veterinary inspection and a free counseling service) can be considered to have successfully accommodate the needs of customers with a variety of facilities and corporate excellence. Based on the research it was concluded that the strategy used in the form of improved relationships with customers through personal selling, promotion price, free inspection, extension livestock and other facilities. Suggestions for the company should maintain an edge marketing strategies implemented in the form of personal selling and promotional strategies, but it is also the company should conduct regular research on consumer behavior animal drugs that strategy actually implemented in accordance with market conditions.
\end{abstract}

\section{PENDAHULUAN}

Subsektor peternakan mempunyai keterkaitan ke belakang (backward inkages) yang tinggi, terutama industri perunggasan dengan industri pakan ternak. Ketergantungan dan tingkat sensitivitas yang tinggi antara keduanya mewarnai pasang surut sektor peternakan di Indonesia. Laju permintaan daging ayam maupun telur sangat tinggi mencapai $8,83 \%$ per tahun selama tiga dasawarsa terakhir. Laju permintaan tersebut pernah anjlok minus 5,25\% per tahun pada masa puncak krisis ekonomi tetapi telah pulih kembali pasca krisis dan mencapai laju permintaan $9,75 \%$ per tahun pada tingkat konsumsi sekitar 820.000 ton per tahun (Nazarudin, 2011). Di samping itu, keterkaitan kedepan (forward linkages) industri perunggasan dengan industri hasil makanan, industri hotel dan restoran, serta sektor pariwiasata lainnya juga demikian vital, maka angka kesempatan kerja dan devisa yang dihasilkan amat besar (Kompas, 2005).

Potensi sumber daya alam Indonesia sangatlah kaya raya dalam menghasilkan dan menyediakan bahan baku pakan maupun sarana lainnya dalam industri perunggasan. Kenyataannya sumber daya lokal berupa teknologi yang dapat menggantikan komponen impor baik pakan, bibit maupun sarana lainnya merupakan kebutuhan yang belum terpenuhi. Kebutuhan tersebut sangat mendesak jika dihubungkan dengan iklim perdagangan bebas yang menghadirkan iklim persaingan terbuka. Pemenuhan kebutuhan juga terasa lebih nyata apabila dikaitkan natara nilai rupiah terhadap dolar AS yang makin menguat, hal ini berdampak langsung terhadap tingkat harga semua sarana produksi perunggasan (AAK, 2003). 
Elemen penting untuk mewujudkan perunggasan yang berdaya saing tinggi di era perdagangan global diantaranya adalah kemampuan meningkatkan produktivitas ternak secara efisien melalui inovasi teknologi. Tuntutan yang tidak kalah penting yaitu harus dikembangkannya rekayasa sosial untuk lebih membudayakan peternakan rakyat sebagai basis usaha perunggasan di negara ini (Hermawatty, 2006).

Salah satu yang mempunyai peranan penting dalam industry perunggasan adalah Pakan. Pakan merupakan input atau sarana produksi yang memiliki nilai strategis, dimana tanpa pakan tidak akanada industri perunggasan. Keberhasilan industri perunggasan dapat diwujudkan lebih maju, efisien dan tangguh jika didukung oleh keberhasilan dalam pengelolaan pakan. Keberhasilan tersebut tercermin dengan terealisasinya standar mutu pakan dan mewujudkan stabilitas harga pakan, juga dapat melakukan pengendalian penyebaran pakan yang sesuai dengan proyeksi kebutuhan konsumsi nasional yang ditargetkan (Hermawatty, 2006).

Hasil proyeksi BPS (2009) yang menunjukkan bahwa jumlah penduduk Indonesia akan terus mengalami peningkatan, yaitu dari 219,8 juta pada tahun 2005 menjadi 247,6 juta pada tahun 2015 dengan laju pertumbuhan penduduk pada tahun 2000 hingga 2010 sebesar 1,49 persen per tahun

(BPS 2010). Sementara itu, kebutuhan konsumsi telur di Indonesia dari tahun ke tahun makin meningkat. Produktivitas peternakan akan meningkat secara tajam di Indonesia. Berdasarkan data Dinas Peternakan, kebutuhan (konsumsi) telur ayam ras mencapai 252.597 $\mathrm{kg}$ per tahun dan telur ayam kampung $314.073 \mathrm{~kg}$ per tahun. Dari data tersebut maka dapat disimpulkan bahwa permintaan telur akan terus meningkat seiring dengan meningkatnya laju penduduk Indonesia. Oleh karena itu sangat diperlukan pengembangan usaha peternakan yang baik untuk memenuhi permintaan pasar.

Produksi telur jika diproyeksikan dengan pasokan pakan masih sangat kurang. Rendahnya produksi tersebut disebabkan masih mahalnya teknologi jika melakukan usaha pembuatan pakan. Saat ini hanya sedikit sekali perusahaan di Indonesia yang memproduksi pakan yang bermutu. Umumnya pembuatan pakan membutuhkan bahan baku yang didatangkan dari luar negeri. Hal ini menyebabkan kebutuhan pasokan pakan sangat mendesak, jika pakan harus diproduksi sendiri untuk memenuhi produksi telur di Indonesia. Untuk menutupi kekurangan dan menyeimbangkan antara produksi dan konsumsinya, maka Indonesia masih harus membeli bahan baku pakan dari luar negeri. Terdapat beberapa hal yang menyebabkan kebutuhan import produk peternakan meningkat, yaitu besarnya jumlah penduduk yang mengkonsumsi produk ternak dan produksi di dalam negeri berkembang relative lambat dibandingkan dengan jumlah kebutuhan konsumsi sehingga memicu impor (Deariana, 1992).

Seiring dengan tingginya kesadaran masyarakat akan pentingnya gizi juga makin meningkatnya permintaan protein hewani maka dibutuhkan banyak persediaan produk peternakan, termasuk pemenuhan permintaan telur unggas yang makin hari makin meningkat. Industri perunggasan khususnya perusahaan atau peternakan ayam di Indonesia harus dapat memenuhi kebutuhan konsumsi telur tersebut.

Industri di bidang peternakan yang dilakukan oleh Satwa Unggul Blitar merupakan salah satu cara untuk memenuhi kebutuhan masyarakat. Satwa Unggul merupakan perusahaan yang didalamnya terdapat unit-unit usaha diantaranya menyediakan obat-obatan unggas, menyediakan pakan dan supplier DOC ayam petelur. Satwa Unggul mendapatkan pakan dari perusahaan besar yang dapat melakukan produksi dalam jumlah besar, kemudian Satwa Unggul melakukan supplier kepada peternak-peternak di Blitar dengan aturan perusahaan 
Satwa Ungggul. Satwa Unggul sangat memerlukan strategi pemasaran yang tepat dalam memasarkan produk-produknya, agar dapat tercapainya tujuan perusahaan.

\section{MATERI DAN METODE PENELITIAN}

\section{Jenis dan Sumber Data}

Jenis data yang digunakan dalam penelitian terdiri dari data primer dan data sekunder, baik yang bersifat kulitatif maupun kuantitatif. Data primer merupakan data yang diperoleh langsung dari wawancara di lapangan dengan pihak perusahaan. Pihak yang diwawancara antara lain manager pemasaran dan manager keuangan/administrasi.Kegiatan wawancara ini untuk mengetahui kegiatan pemasaran.

Data sekunder adalah data yang didapat dari literature-literatur dan instansi yang ada. Data sekunder yang didapat dari Satwa Unggul mengenai gambaran umum perusahaan seperti sejarah, struktur organisasi dan pemasaran. Juga data sekunder ini didapat melalui instansi terkait seperti Badan Pusat Statistik, Deperindag dan bahan pustaka lain yang relevan.

\section{Metode Pengumpulan Data}

Dari pengumpulan data melalui wawancara, diidentifikasikan kegiatan pemasaran dan tujuan utama, faktor yang mendukung dalam pemilihan alternatif strategi pemasaran yang tepat bagi perusahaan. Alternatif tersebut dibuat dengan mempertimbangkan kendala-kendala yang dihadapi dan pendukung perusahaan.

Kuisioner diberikan kepada menejer pemasaran dan menejer administrasi. Pemilihan dilakukan secara purposive dengan pertimbangan responden sebagai pihak-pihak yang mengetahui kegiatan pemasaran dan pengembangan usaha. Pemberian kuesioner dilakukan untuk menganalisis pemilihan alternatif strategi yang paling tepat bagi perusahaan.

\section{Metode Pengolahan Data dan Analisis Data}

Metode pengolahan dan analisis data yang digunakan adalah melalui pendekatan konsep bauran pemasaran. Pengolahan data diperlukan untuk menganalisis faktor-faktor yang berpengaruh dalam menyusun sasaran yangmerupakan priorotas utama dalam pemilihan strategi pemasaran yang tepat. Setelah itu data tersebut dikelompokkan dengan menggunakan analisis deskriptif.

\section{HASIL DAN PEMBAHASAN}

\section{Pemasaran}

Pemasaran merupakan salah satu kegiatan perusahaan untuk mempertahankan keberadaan produknya, terutama dalam keadaan permintaan pasar yang tidak stabil. Dalam situasi persaingan, perusahaan harus menerapkan strategi pemasaran yang dinamis dan disesuaikan dengan kondisi pasar yang ada. Satwa Unggul melakukan strategi pemasaran dengan bauran pemasaran (marketing mix), yang mengkombinasikan variabel produk, harga, distribusi dan promosi.

\section{Strategi Produk}

Strategi produk yang dilakukan oleh perusahaan meliputi strategi keputusan atribut produk, kemasan dan pelabelan produk. Strategi ini lebih banyak berhubungan dengan pengelolaan produk sebelum maupun pada saat produk yang bersangkutan berada dipasar. Strategi brand image untuk merek produk digunakan oleh perusahaan untuk memberi ingatan pada konsumen bahwa produk tersebut berasal dari perusahaan .

Dalam menghasilkan kualitas produk yang baik, produsen memperhatikan beberapa faktor berikut:

Bahan Baku 
Bahan baku yang digunakan oleh perusahaan adalah BKK,MBM,Tepung Ikan dll. Kualitas bahan baku selalu menjadi perhatian perusahaan, karena produk yang baik dapat terbentuk dari kualitas bahan baku yang baik. Mayoritas bahan baku harus diimpor untuk menjaga kualitas produk untuk memenuhi standar internasional. Tabel 1 menunjukkan produk bahan baku yang dibutuhkan dalam proses produksi pakan ternak.

\section{Tabel 1. Beberapa Bahan Baku dan Asal Perusahaan Pembuatan Pakan Ternak}

\begin{tabular}{|c|l|c|}
\hline No. & \multicolumn{1}{|c|}{ Nama Bahan Baku } & Asal Perusahaan \\
\hline 1. & BKK & Multindo/ Panca Patriot \\
2. & PMM & Multindo/ Panca Patriot \\
3. & CGM & Multindo/ Panca Patriot \\
4. & MBM & Multindo/ Panca Patriot \\
5. & Grit & Anonim \\
\hline
\end{tabular}

Sumber : Satwa Unggul, 2013

Produk merupakan unsur penting dalam sebuah industri.Kualitas produk yang baik dapat menjadi keunggulan sebuah perusahaan.Satwa Unggul memiliki produk yang memiliki kualitas yang baik. Hal tersebut sesuai dengan pendapat beberapa konsumen yang ditemui oleh peneliti di perusahaan ketika sedang melakukan pemesanan pakan ternak. Kualitas pakan dapat tetap terjaga karena pakan dibuat dari bahan impor yang memenuhi standar kesehatan pakan ternak internasional.

\section{Kemasan}

Produk dipasarkan dalam karung yang dikemas $50 \mathrm{~kg}$. Pelabelan pada kemasan terlihat dengan jelas. Nama produk dan nama perusahaan tertulis dominan pada tampilan depan kemasan untuk menghindari pemalsuan produk. Kemasan bergambar ayam sebagai lambang pakan untuk unggas. Berdasarkan wawancara yang dilakukan terhadap beberapa konsumen, dapat dilihat bahwa Satwa Unggul memiliki kemasan yang cukup baik. Hal tersebut dapat dilihat pada bungkus kemasan dengan warna, gambar, dan tulisan yang menarik. Produk dikemas secara steril dan harus segera digunakan ketika kemasan dibuka untuk menjaga pakan agar tidak kontak langsung dengan udara bebas. Komposisi dan kandungan pakan dapat terlihat jelas pada label kemasan. Cara pemakaian dan tanggal kadaluarsa pakan secara berkala dikontrol oleh dokter hewan yang ditugaskan oleh perusahaan.

\section{Strategi Harga}

Strategi harga merupakan strategi yang penting bagi manajemen. PT Satwa Unggul menetapkan harga jual produk berdasarkan biaya produksi ditambah dengan profit yang disesuaikan dengan harga jual produk sejenis dari perusahaan lain. Harga yang dijual relatif sama dengan produsen lain, tapi perusahaan dapat memadukan strategi harga dengan strategi promosi dengan memberikan potongan harga, jika pelanggan membeli dengan cara tunai atau membeli dalam jumlah besar. Tingkat perbandingan beberapa produk perusahaan berdasarkan perbandingan harganya dengan perusahaan kompetitor dapat dilihat pada Tabel 2.

Tabel 2. Perbandingan Harga Jual Produk Satwa Unggul dengan Kompetitornya Tahun 2013

\begin{tabular}{|c|c|c|c|c|c|c|c|}
\hline \multicolumn{2}{|c|}{ Satwa Unggul } & \multicolumn{2}{c|}{$\begin{array}{c}\text { Kompetitor A } \\
\text { (Japfa Comfeed) }\end{array}$} & \multicolumn{2}{c|}{$\begin{array}{c}\text { Kompetitor B } \\
\text { (Malindo) }\end{array}$} & \multicolumn{2}{c|}{$\begin{array}{c}\text { Kompetitor C } \\
\text { (Charoen Phokpan) }\end{array}$} \\
\hline $\begin{array}{c}\text { Nama } \\
\text { Produk }\end{array}$ & $\begin{array}{c}\text { Harga } \\
\text { (Rp) } \\
\text { /sak }\end{array}$ & $\begin{array}{c}\text { Nama } \\
\text { Produk }\end{array}$ & $\begin{array}{c}\text { Harga } \\
\text { (Rp) } \\
\text { /sak }\end{array}$ & $\begin{array}{c}\text { Nama } \\
\text { Produk }\end{array}$ & $\begin{array}{c}\text { Harga } \\
\text { (Rp) } \\
\text { /sak }\end{array}$ & $\begin{array}{c}\text { Nama } \\
\text { Produk }\end{array}$ & $\begin{array}{c}\text { Harga } \\
\text { (Rp) } \\
\text { /sak }\end{array}$ \\
\hline
\end{tabular}




\begin{tabular}{|l|l|l|l|l|l|l|l|}
\hline Komp.Bro & 260.000 & RN 42 & - & BR Super & 302.000 & 511 & 305.000 \\
Sentrat G & 256.000 & RN 62 & 303.000 & M1 & 313.000 & 124 & - \\
KTA & 290.000 & RN 69 & 318.000 & M2 & 304.000 & $124 \mathrm{P}$ & 308.000
\end{tabular}

Sumber : Satwa Unggul 2013

Berdasarkan Tabel 2, dapat dilihat bahwa beberapa produk Satwa Unggul dijual jauh lebih murah dibandingkan dengan produk sejenis dengan nama yang berbeda dari kompetitornya. Akan tetapi, walaupun nama produk berbeda, namun fungsi pakan tersebut sama.

Namun demikian,semua produk perusahaan dijual dengan harga sedikit lebih murah dari perusahaan besar yang lain karena perusahaan lain telah lebih dulu memiliki nama dan produk yang dihasilkan jauh lebih baik dibanding produk Satwa Unggul. Hal tersebut sesuai dengan pernyataan beberapa konsumen yang ditemui, yang menyatakan bahwa Satwa Unggul memiliki harga jual produk yang cukup baik. Harga jual beberapa produk cukup kompetitif, sedikit lebih murah jika dibandingkan dengan produk sejenis yang diproduksi oleh perusahaan lain. Konsumen memiliki bargaining position yang kuat dibandingkan dengan produsen.Hal tersebut disadari karena jumlah produsen pakan ternak yang banyak jika dibandingkan dengan jumlah peternak sebagai konsumen relatif tetap dari tahun ke tahun.

\section{Strategi Distribusi}

Strategi distribusi dapat digunakan untuk melihat konsistensi perusahaan dalam sebuah industri. Semakin banyak produknya beredar, semakin mudah konsumen mendapatkannya, maka semakin mudah merek produk tersebut masuk kedalam ingatan konsumen. Satwa Unggul menggunakan penyebaran sales penjualan dan dokter hewan kepeternakan-peternakan terdekat untukmemberikan penyuluhan, melakukan pendekatan individu dalam menyebarkan produknya.

Pemasaran dengan pendekatan pribadi (personal selling) menjadi keunggulan bagi perusahaan. Hal tersebut direspon secara positif oleh konsumen, karena konsumen dapat memperoleh informasi yang jelas mengenai penggunaan pakan ternak. Sales sudah cukup menguasai materi tentang produk dan mengetahui sedikitnya tentang perkembangan peternakan di Indonesia. Sales penjualan selalu mencari peternakan-peternakan lain yang belum ia datangi untuk memasarkan produk perusahaan. Sales dilengkapi dengan fasilitas kendaraan bermotor roda dua untuk membantu pekerjaannya.

Namun demikian, perusahaan juga memiliki kelemahan dalam hal keterlambatan waktu pengiriman (time lag). Hal tersebut dapat dilihat dari waktu pengantaran yang sering terlambat. Hal tersebut dirasa sangat merugikan

konsumen, karena mereka seringkali harus menunggu barang pesanannya. Hal itu sudah disadari oleh pihak perusahaan sebagai suatu kelalaian karena proses transportasi yang sering bermasalah, baik dalam hal penyediaan stok gudang cabang yang terlalu sedikit maupun waktu pesan yang terkadang bersamaan dengan pesanan pihak lain.

Saluran distribusi memegang peranan penting dalam penyebaran produk. Memilih saluran distribusi yang tepat dapat membantu meningkatkan volume penjualan. Menyadari pentingnya hal tersebut, Satwa Unggul menggunakan tiga jenis saluran distribusi untuk mengakomodasi kebutuhan pakan ternak dalam negeri. Pola distribusi pertama langsung dipasarkan ke peternak. Pola ini merupakan keunggulan perusahaan, karena dapat berinteraksi la ngsung dengan peternak. Pola kedua dan ketiga melalui pelantara, namun perusahaan tetap memperhitungkan tingkat keefektifannya. Ketiga pola distribusi tersebut menggunakan sistem personal selling dalam mendistribusikan obat hewan dari perusahaan kepada konsumen tingkat pertama yang digambarkan dengan tanda panah. Perusahaan bertanggung jawab terhadap pendistribusian hanya sampai konsumen tingkat pertama, sedangkan proses distribusi selanjutnya menjadi tanggung jawab pihak distributor pakan ternak. 


\section{Analisis Faktor-Faktor Eksternal Analisis Lingkungan Jauh}

(1) Faktor Ekonomi

Ekonomi adalah sebuah indikator berkembangnya suatu negara. Keadaan ekonomi yang baik dapat mendorong perkembangan industri. Di Indonesia, pertumbuhan ekonomi dihitung berdasarkan Gross Domestik Product (GDP). Berdasarkan data BPS, laju pertumbuhan ekonomi di Indonesia pada tahun 2008 sebesar 4.2 persen. Kondisi tersebut semakin baik dan meningkat sebesar 5.6 persen pada tahun 2007. Menurut data Mark Plus \& Co (2007), nilai GDP perkapita Indonesia pada tahun 2008 sebesar US \$ 1.191 milion mengalami peningkatan menjadi US \$ 1.219 milion pada tahun 2009. Hal tersebut mengindikasikan bahwa industi dapat berkembang dengan pesat.

Indikator lain yang perlu diperhatikan adalah laju inflasi. Angka ini menggambarkan stabilitas suatu negara. Berdasarkan data BPS, tingkat inflasi Indonesia naik tajam hingga 16.8 persen pada akhir tahun 2008. jika sebelumnya hanya berkisar 6.1 persen. Hal tersebut terjadi karena naiknya harga bahan bakar minyak (BBM) yang memberikan dampak pada perusahaan karena harus menaikkan harga jual produknya.

Indikator ekonomi yang sangat mempengaruhi perkembangan perusahaan adalah nilai tukar rupiah terhadap mata uang asing (kurs). Hal tersebut mempengaruhi biaya produksi perusahaan karena sebagian besar bahan baku pembuatan obat hewan harus diimpor dari luar negeri. Perusahaan pernah mengalami kegoncangan produksi pada saat terjadi krisis ekonomi beberapa tahun lalu. Hal tersebut terjadi karena nilai kurs rupiah tidak stabil dan perusahaan mengalami kerugian karena ketidak-seimbangan antara biaya produksi dengan harga jual produk yang ditetapkan.

(2) Faktor Sosial, Budaya dan Demografi

Indonesia merupakan negara yang memiliki tingkat populasi yang cukup besar yaitu 215.3 juta jiwa (BPS, 2007).59 persen dari jumlah penduduknya menempati pulau Jawa. Peningkatan jumlah penduduk tersebut berdampak pada semakin besarnya jumlah angkatan kerja yang tersedia di pulau Jawa. Maka dari itu, mayoritas kegiatan industri berada di pulau Jawa.

Berdasarkan aspek sosial budaya, penduduk Indonesia mengalami perubahan gayahidup. Saat ini, penduduk lebih memperhatikan kesehatan yang dalam hal ini pemenuhan gizi dengan makanan yang mengandung gizi.Masyarakat sudah terbiasa mengkonsumsi daging untuk penganan makan sehari-hari. Arus globalisasi dapat merubah gaya hidup sebagian kalangan untuk lebih memperhatikan asal mula daging dan lebih peduli terhadap perkembangan hewan, baik untuk hewan ternak ataupun hewan peliharaannya. Pergeseran gaya hidup ini menciptakan perilaku animal care pada sebagian kalangan. Perawatan dan perkembangan hewan membutuhkan obat hewan untuk menjaga kesehatan hewan, baik untuk hewan peliharaan maupun untuk hewan yang diternakkan. Satwa Unggul memanfaatkan peluang bisnis ini dengan menyediakan pakan obat hewan untuk menyokong bidang peternakan sebagai penghasil daging.

\section{(3) Faktor Politik, Pemerintahan dan Hukum}

Kondisi politik sebuah negara dapat mempengaruhi perkembangan suatu industri. Saat ini industri pakan dan obat hewan kurang mendapat perhatian dari pemerintah. Namun setelah merebaknya virus flu burung pada pertengahan tahun 2008, pemerintah mengeluarkan regulasi tentang pemusnahan unggas yang diduga terinfeksi virus flu burung dengan penggantian uang senilai Rp. 10000 tiap ekor unggas yang dimusnahkan oleh pemerintah. Hal 
tersebut membawa dampak negatif bagi perusahaan, karena permintaan akan pakan ternak menurun. Hal ini disebabkan oleh penurunan jumlah unggas sebagai pengguna pakan karena kebijakan pemusnahan tersebut.

(4) Faktor Teknologi

Teknologi merupakan faktor penting dalam industri pakan. Hal tersebut terjadi karena proses pembuatan pakan harus memiliki standarisasi kesehatan dan kontrol yeng tinggi untuk menjaga strerilisasi dan kualitas produk, yang hanya dapat dilakukan oleh alat-alat dan mesin- mesin berteknologi tanggi dengan standart internasioanal. Perusahaan menggunakan mesin- mesin berat, pencetak pakan secara masal dengan mengadopsi teknologi terbaru.Peralatan lainnya juga digunakan sebagai fasilitas pendukung.

\section{Analisis Lingkungan Industri}

(1) Ancaman Pendatang Baru

Kondisi ekonomi yang semakin membaik, membuka peluang bagi perusahaan yang bergerak di bidang pakan ternak untuk berkembang. Hal ini juga dapat dimanfaatkan oleh perusahaan lain yang belum terjun di bidang pakan ternak turut ambil bagian. Indusri pakan ternak merupakan industri berat yang membutuhkan teknologi tinggi. Hal ini yang membuat hambatan masuk industri pakan ternak tinggi. Hanya produsen yang mempunyai modal yang cukup dan dapat mengadopsi teknologi tinggi yang dapat masuk kedalam industri ini. Melihat hambatan masuk industri yang cukup besar, maka perusahaan yang bergerak di bidang industri pakan ternak sebagian besar didominasi oleh perusahaan-perusahaan lama yang memiliki pangsa pasar diatas dua persen.

(2) Ancaman Produk Pengganti

Ancaman produk pengganti untuk industri pakan ternak yaitu pakan sejenis dengan merek lain dengan harga yang lebih murah. Oleh karena itu, setiap produsen pakan ternak harus selalu mewaspadai munculnya ancaman produk pengganti dengan melakukan survei secara berkala untuk mengikuti perkembangannya.

(3) Kekuatan Tawar Menawar Pembeli

Kekuatan tawar menawar pembeli pada industri pakan ternak cukup kuat karena konsumen bisa memilih produk mana saja yang mereka inginkan. Hal tersebut terjadi karena banyaknya perusahaan pakan meningkat walaupun sedikit jumlahnya, sedangkan jumlah peternakan relatif sama dari tahun ke tahun. Seluruh produsen menggunakan semua sumber dayanya untuk memperebutkan pangsa pasar yang ada, sehingga terjadi perang harga antar produsen. Konsumen seringkali terpengaruh dengan harga yang lebih murah dan melihat produsen secara objektif, sehingga konsumen dapat memilih produsen mana saja yang mereka sukai.

Hal ini menjadi perhatian khusus bagi Satwa Unggul untuk bersaing dipasar. Satwa Unggul menggunakan promosi penjualan dengan potongan harga, pelayanan konsultasi, dan melakukan pendekatan secara personal untuk mempertahankan pelanggannya agar tidar beralih kepada produsen lain.

(4) Kekuatan Tawar Menawar Pemasok

Satwa Unggul tidak memproduksi semua pakan sendiri. Perusahaan membutuhkan pemasok bahan baku dan ini harus impor dari luar, yaitu : Argentina,Brazil,India. Jadi, tidak mudah untuk mendapatkan pemasok yang benar-benar sesuai dengan kualifikasi produk, sehingga kekuatan tawar pemasok cukup kuat untuk industri ini.

Ketergantungan perusahaan pada pemasok bahan baku di luar negeri dapat memberikan dampak negatif jika terjadi permasalahan dalam kerjasamanya dengan pemasok. Oleh karena itu, perusahaan sedang melakukan pendekatan dengan pemasok lain sebagai tindakan antisipasi jika terjadi permasalahan dalam pasokan bahan baku. Perusahaan juga 
membuat kontrak eksklusif selama beberapa tahun dengan perusahaan pemasok bahan baku yang berasal dari dalam negeri.

(5) Tingkat Revalitas Pesaing yang Ada

Industri pakan masih dikuasai oleh perusahaan-perusahaan lama, seperti : Charoen

Phokpan,Japfa,Cargil,Wonokoyo dan lain sebagainya. Mereka bersaing untuk memperebutkan pangsa pasar yang ada. Semakin lama persaingan mengarah ke promosi negatif, seperti : memberikan produk, bahkan uang sogokan kepada pelanggan agar tetap mengadakan kerjasama (kolusi), dan mempengaruhi peternak bahwa produk dari produsen lain memiliki kualitas yang tidak baik.

\section{Analisis Lingkungan Operasi}

\section{1) Analisis Pesaing}

Pesaing merupakan ancaman bagi perusahaan. Persaingan yang ada semakin lama mengarah kepada persaingan yang tidak sehat seperti telah dibahas sebelumnya. Satwa Unggul menggunakan pendekatan secara personal kepada para peternak dengan menjaga kualitas produk dan memberikan berbagai fasilitas seperti konsultasi, penyuluhan, potongan harga dan lain sebagainya.

2) Analisis Konsumen

Konsumen adalah alasan terbesar mengapa suatu perusahaan berdiri. Satwa Unggul selalu berusaha untuk memberikan pelayanan terbaik. Perusahaan membuka layanan pengaduan konsumen melalui telepon 0342-814260 atau 0342-815061 dan fax 0342-814260 untuk kantor pusat yang berada di Blitar-Jawa Timur. Untuk pengaduan layanan konsumen di daerah, dapat menghubungi kantor cabang di tiap daerah.

\section{3) Analisis Pemasok}

Pemasok merupakan unsur penting untuk keberlangsungan sebuah perusahaan. Satwa Unggul melakukan kerjasama melalui kontrak eksklusif dengan para pemasok untuk menghindari permasalahan yang mungkin timbul dalam pemenuhan pasokan barang.

\section{KESIMPULAN DAN SARAN Kesimpulan}

Berdasarkan hasil penelitian, maka dapat diambil kesimpulan sebagai

berikut :

1. Strategi bauran pemasaran yang tengah dilakukan oleh perusahaan yang menyangkut strategi produk (berupa brand awareness atas merek), strategi harga (berupa potongan harga), strategi distribusi (berupa tiga pola distribusi), dan strategi promosi (berupa pemeriksaan hewan dan layanan penyuluhan gratis) dapat dinilai telah berhasil mengakomodasi kebutuhan pelanggan dengan berbagai fasilitas dan keunggulan perusahaan.

2. Berdasarkan analisis dapat dilihat bahwa Satwa Unggul memiliki posisi internal yang kuat. Hal ini berarti perusahaan telah mampu menggunakan kekuatan dan mengatasi kelemahannya dengan cukup baik. Kekuatan yang dimiliki oleh perusahaan berupa : harga yang terjangkau, kualitas produk baik, tenaga kerja terspesialisasi, penjualan dengan personal selling, dan sasaran penjualan pada peternak besar. Sedangkan kelemahan perusahaan berupa : kuatnya pengaruh pimpinan, keterbatasan modal, keterlambatan waktu 
pengiriman, tidak ada kontrak eksklusif dengan pelanggan, dan tidak adanya kegiatan litbang. Berdasarkan analisis lingkungan eksternal, dapat dilihat bahwa PT Satwa Unggul juga memiliki posisi eksternal yang kuat, karena telah mampu memanfaatkan peluang dan dapat mengatasi ancaman dengan cukup baik. Peluang yang dimiliki perusahaan berupa : peningkatan konsumsi daging nasional, cukup tersedia angkatan kerja, kemajuan teknologi, perilaku animal care, dan hambatan masuk industri tinggi. Sedangkan ancaman yang masuk berupa : kekuatan tawar- menawar pemasok dan pembeli cukup kuat, meningkatnya laju inflasi, fluktuasi nilai tukar rupiah, dan tingginya tingkat persaingan.

3. Alternatif strategi yang dapat dilakukan oleh Satwa Unggul dalam mempertahankan dan meningkatkan kegiatan perusahaannya antara lain berupa peningkatan hubungan baik dengan pelanggan melalui personal selling, promosi harga, pemeriksaan gratis, penyuluhan ternak danfasilitas lainnya.

\section{Saran}

Berdasarkan hasil penelitian, didapat beberapa hal yang harus diperhatikan dalam perkembangan industri obat hewan. Maka peneliti ingin memberikan saran dan masukan sebagai bahan pertimbangan untuk perbaikan dimasa yang akan datang. Saran tersebut diantaranya :

1. Perusahaan sebaiknya mempertahankan keunggulan strategi pemasaran yang dijalankan berupa personal selling dan strategi promosi. Personal selling sebagai strategi penguat dari strategi promosi iklan yang selama ini diterapkan oleh perusahaan. Perusahaan juga memperbaiki kelemahannya dalam keterlambatan waktu pengiriman (time lag) untuk menambah kepercayaan konsumen kepada perusahaan dengan cara : memuat stok barang dalam umlah besar pada seluruh anak cabang perusahaan dan memberikan garansi bonus barang jika pengantaran lebih dari 2x24 jam.

2. Perusahaan dapat menggunakan promosi dengan mendirikan posko-posko atau balai-balai konsultasi dan layanan peternakan disekitar wilayah peternakan yang dilengkapi dengan pemasangan atribut dan merek obat untuk menciptakan ingatan akan merek pada konsumen. Satwa Unggul sebagai produsen obat hewan sebaiknya melakukan riset secara berkala mengenai perilaku konsumen obat hewan agar strategi yang diterapkan benar-benar sesuai dengan kondisi pasar dengan cukup baik. Peluang yang dimiliki perusahaan berupa : peningkatan konsumsi daging nasional, cukup tersedia angkatan kerja, kemajuan teknologi, perilaku animal care, dan hambatan masuk industri tinggi. Sedangkan ancaman yang masuk berupa : kekuatan tawar- menawar pemasok dan pembeli cukup kuat, meningkatnya laju inflasi, fluktuasi nilai tukar rupiah, dan tingginya tingkat persaingan.

4. Alternatif strategi yang dapat dilakukan oleh Satwa Unggul dalam mempertahankan dan meningkatkan kegiatan perusahaannya antara lain berupa peningkatan hubungan baik dengan pelanggan melalui personal selling, promosi harga, pemeriksaan gratis, penyuluhan ternak danfasilitas lainnya.

\section{DAFTAR PUSTAKA}

Alfredo. 2005. Analisis Strategi Pemasaran Meubel Berdikari Furniture. Skripsi Sarjana. Departemen Sosial Ekonomi Pertanian, Fakultas Pertanian, Institut Pertanian Bogor. Bogor. 
Badan Pusat Statistik. http://www.bps.go.id

. 2004. Statistik Indonesia. Jakarta. 2004. Statistik 60 Tahun Indonesia Merdeka. Jakarta. 2004. Statistik Konsumsi Daging Indonesia. Jakarta. Cahyono,

Bambang Tri. 1996. Manajemen Pemasaran. IPWI. Jakarta.

David, Fred R. 2002. Manajemen Strategis. Alih Bahasa Alexander Sindoro. Prenhallindo. Jakarta.

Direktorat Jendral Peternakan. 2004. BahanStatistik Peternakan.

Engel, James F, dkk. 1994. Perilaku Konsumen. Alih Bahasa Budiyanto. Binarupa Aksara. Jakarta.

Ikhsan, Benil. 2005. Peran Sektor Peternakan Unggas dan Dampak Flu BurungTerhadap Kinerja Sektor Ekonomi di Indonesia. Skripsi Sarjana.Departemen Sosial Ekonomi Pertanian, Fakultas Pertanian, Institut Pertanian Bogor. Bogor.

Ilmawan, Taufik. 2003. Pola Penentuan Ternak Unggas Lokal Unggulan di Tiga Desa yang Berbeda Bio-klimatnya di Kabupaten Cianjur. Departemen Ilmu Produksi Ternak, Fakultas Peternakan, Institut Pertanian Bogor. Bogor.

Kotler, Philip. 2000. Manajemen Pemasaran. Alih Bahasa Hendra Teguh,dkk. Prenhallindo. Jakarta.

Nazir, Mohammad. 1999. Metode Penelitian. Ghalia. Jakarta.

Porter, Michael E. 1994. Keunggulan Bersaing. Binarupa Aksara. Jakarta. Suharno,

Bambang. 2005. Data Bisnis Peternakan. Gita Pustaka. Jakarta.

Suhendi, Endi. 1997. Analisis Strategi Promosi Obat Hewan. Tesis Magister (yang tidak dipublikasikan), Sekolah Tinggi Ilmu Ekonomi IPWI. Jakarta.

Sumawihardja, Surachman. 1991. Intisari Manajemen Pemasaran. Rosda. Bandung.

Triakoso, Budi. 1998. Kesehatan Unggas. Kanisius.Yogyakarta. 